Geopolítica(s) Revista de estudios sobre espacio y poder ISSN: 2172-3958

\title{
The Principle of the New World Order ${ }^{1}$
}

\author{
Kitarō Nishida
}

\begin{abstract}
The First World War created no other principles for world formation than an abstract notion of national self-determination. Such an abstract notion could not solve the historical challenges the world faced, of which the outbreak of the Second World War provided evidence. Each state/nation must realize its world-historical mission to construct the world-historical world in which states/nations would be united to form 'a global world (sekai-teki sekai)' while maintaining their own historical uniqueness. For such historically unique entities to be united into the whole without losing their uniqueness, it would be necessary an intermediate process of forming 'a particular world (tokushu-teki sekai)'. In this process, each state/nation transcends itself, connects to neighboring states/nations, and follows its own regional (supra-national) tradition at the same time, leading to the establishment of non-Western worlds. East Asian nations must realize their world-historical mission and construct a particular world based on the idea of East Asian culture. There must be a central player to tackle such challenges and no country but Japan would be in the position to play such a role. Keywords: Kitarō Nishida; geopolitics; Japanese Philosophy; East Asia Co-prosperity Sphere; new world order.
\end{abstract}

\section{[es] El principio del nuevo orden mundial}

Resumen. La Primera Guerra Mundial no creó otros principios para la formación mundial más que una noción abstracta de autodeterminación nacional. Una noción tan abstracta no podría resolver los desafíos históricos que enfrentó el mundo, lo que quedó demostrado por el estallido de la Segunda Guerra Mundial. Cada Estado-y-nación debe realizar su misión histórica mundial para construir el mundo histórico-mundial en el que los Estados-y-nación se unirían para formar "un mundo global" (sekai-teki sekai) mientras mantienen su propia singularidad histórica. Para que esas entidades históricamente únicas se unan en el todo sin perder su singularidad, sería necesario un proceso intermedio de formación de "un mundo particular" (tokushu-teki sekai). En este proceso, cada Estadoy-nación se trasciende a sí mismo, se conecta con los Estados-y-nación vecinos, y sigue su propia tradición regional (supranacional) al mismo tiempo, lo que lleva al establecimiento de mundos no occidentales. Las naciones del Este asiático deben realizar su misión histórico-mundial y construir un

1 (Editor's note) 'The Principle the New World Order' was written in 1944 and included in the second edition of Nishida Kitarō Zenshü (The Complete Works of Kitarō Nishida) in 1966 (Iwanami Shoten, 1966, Vol. 12, pp. 426-434). The essay is also available on-line at https://www.aozora.gr.jp/cards/000182/files/3668_16431.html (accessed 18 March 2019). Translated by Takashi Yamazaki. Arisaka (1996) also has a full translation of 'The Principle' which is referred to for this translation. The organization of the paragraphs in the original text has been changed to make reading easier. Blank lines, however, are inserted as they are in the original text. References are included in the posterior Commentary. 
mundo particular basado en la idea de la cultura del Este asiático. Debe haber un jugador central para enfrentar tales desafíos y no habría otro país más que Japón para desempeñar ese papel.

Palabras clave: Kitarō Nishida; geopolítica; filosofía japonesa; Esfera de Co-prosperidad del Asia Oriental; nuevo orden mundial.

\section{[pt] O principio do novo ordem mundial}

Resumo. A Primeira Guerra Mundial não criou outros princípios para a formação mundial além de uma noção abstrata de autodeterminação nacional. Tal noção abstrata não poderia resolver os desafios históricos que o mundo enfrentava, o que foi demonstrado pelo início da Segunda Guerra Mundial. Cada estado-e-nação deve cumprir sua missão histórica mundial para construir o mundo histórico mundial no qual os estados-e-nação se uniriam para formar "um mundo global" (sekai-teki sekai), mantendo sua própria singularidade histórica. Para que essas entidades historicamente únicas se unam no todo sem perder sua singularidade, seria necessário um processo intermediário de formação de "um mundo particular" (tokushu-teki sekai). Nesse processo, cada estado-e-nação se transcende, se conecta com os estados-e-nação vizinhos e segue sua própria tradição regional (supranacional) ao mesmo tempo, levando ao estabelecimento de mundos não ocidentais. Os países do leste asiático devem cumprir sua missão no mundo histórico e construir um mundo particular, com base na idéia da cultura do leste asiático. Deve haver um ator central para enfrentar esses desafios e não haveria outro país além do Japão para desempenhar esse papel.

Palavras-chave: Kitarō Nishida; geopolítica; filosofia japonesa; Esfera de Co-prosperidade da Asia Oriental; novo ordem mundial.

How to cite: Nishida, Kitarō (2019) "The Principle of the New World Order". Geopolitica(s). Revista de estudios sobre espacio y poder, vol. 10, núm. 2, 305-311.

The world has its own challenges in each era and moves from one era to another seeking their solutions. In the case of Europe, the eighteenth century was an era of individualistic self-awakening, or of so-called individualism and liberalism. In the eighteenth century, the world had not yet reached the stage of inter-state conflicts in a single historical world. It can roughly be said that the United Kingdom dominated the seas while France controlled the lands.

In the nineteenth century, however, Germany conflicted with France in a historical world called Europe, which finally led to the confrontation between the two great powers, Germany and the United Kingdom, in a global space. This was the cause of the First World War. The nineteenth century was an era of state selfawareness, or so-called imperialism. Each state thought that its historical mission was to strengthen itself by infinitely subordinating other states.

This, however, was not yet the stage of the state's self-awareness of its worldhistorical mission [emphasis original]. As long as states are simply based on imperialism without realizing their world-historical mission, they cannot avoid class struggles on the flip side. Since the nineteenth century, the world has been in an era of class struggles as well as imperialism. Although communism is totalitarian, its principle is still based on the eighteenth-century abstract idea of the world constructed by individualistic self-awareness. It can also be seen as a resistance against nineteenth-century thought. Communism belongs to the past like imperialism. 
Today's world, I think, is the era of global self-awareness. Each state must be aware of its own world [i.e. world-historical] mission in order to constitute $a$ world-historical world, that is, a global world [emphasis original]. ${ }^{2}$ This is the historical challenge of the present time. The world already entered this stage in the First World War. The end of the War, however, left the challenge unsolved and created no new principle for world formation except the old abstract idea of the world. This is the reason world war is repeated now. The current world war urgently demands a solution to this challenge. ${ }^{3}$

When powerful states are confronted with each other in a global space, the world cannot help entering fierce struggles. As a result of scientific, technological, and economic development, states and nations have entered a closely connected global space. The only way to solve this challenge is for states/nations ( kokka minzoku) to form a global world by realizing their world-historical mission, or by constantly developing and transcending themselves at the same time. ${ }^{4}$ That is why I call the modern times the era of the global self-awareness by states/nations.

National self-determinism is said to equally recognize the independence of each nation as seen in the Wilsonian League of Nations. It does not mean, however, that states/nations form a global world by transcending themselves. Such a worldview is based on the abstract idea of the world in the eighteenth century. The current world war proves that such an idea cannot solve actual historical challenges.

In fact, each state/nation is established on its own historical foundation and has its own world-historical mission, which enables it to have its own historical life. For states/nations to form a global world by both developing and transcending themselves must means that each of them first forms a particular world by transcending itself and following its own regional tradition at the same time [emphasis original].

Then, such worlds that are constructed on historical foundations would connect with each other and transform the whole world into a single global world. In such a global world, each state/nation would live its own unique historical life and connect itself to a global world by fulfilling its own world-historical mission. This is the ultimate idea of human historical development and must be the principle of the new world order demanded by the current world war. The idea of 'Eight corners of the world under one roof' (hakko ichiu) in our country seems to represent such a principle. The Emperor graciously declared to allow all states to

2 (Translator's note) As Arisaka (1996: 100, note 92) points out, Nishida used 'world-historical' (sekaishi-teki) as a translation of Hegel's terminology weitgeschichtlich. As mentioned below in the text, Nishida distinguished 'world-historical world' or 'worldwide world' (sekaiteki sekai) from mere 'world'. For him, the world-historical world is the concrete idea of the world in which all states and nations "realize their fullest participation in world history" (Arisaka, 1996: 101, note 96). Thus, the world-historical world is regarded as more inclusive and multicultural than the world dominated by Western imperialism. According to Arisaka (1996), this translation also uses the term 'global world' to represent 'world-historical world' or 'worldwide world'. Ōhashi (2001: 27-28, note 8), on the other hand, proposes the use of 'world-ly world' that he thinks has a nuance closer to the original Japanese term.

3 (Translator's note) That is, a task to form the new world order that embraces the concrete realities of states/nations.

4 (Translator's note) One of the typical philosophical arguments Nishida made to represent the process in which states/nations are united to form a global world while maintaining their own historical uniqueness. 
obtain their own places. ${ }^{5}$ I respectfully infer that this imperial command makes an important point. This principle could also solve the problems related to the communist cosmopolitanism based on the eighteenth-century thought.

If the challenges posed by the current world war and the principle of the new world order are as stated above, then they must naturally formulate the principle of the East Asia Co-prosperity Sphere. European imperialism has so far oppressed and colonized East Asian nations and deprived them of their world-historical mission. Now East Asian nations must realize their world-historical mission, form a particular world by transcending themselves, and carry out the world-historical mission of East Asian nations. This is the principle of the formation of East Asia Co-prosperity Sphere. Now we, East Asian nations, must join together for the idea of East Asian culture and rouse ourselves according to our world-historical mission. Then, in order to form a particular world, there must be a candidate who plays a central role in tackling such challenges. In East Asia today, there is no other country than Japan that can assume such a position. The victory of ancient Greece in the Persian War is said to have determined the direction of the cultural development of the European world until today. Likewise, [the situation of Japan during] the current war in East Asian will determine the future direction of world history.

The moral principles of the current world are neither Christian philanthropy nor the so-called royal road of ancient China $(\bar{o} d \bar{o})$. Rather, they must be that states/nations form a global world by transcending themselves to become the constructors of a global world. Our national polity is not merely totalitarian. The Imperial House embodies the absolute present (zettai genzai) that contains the elements of the past and the future. It thus represents the beginning and the end of our [Japanese] world. The quintessence of the unbroken imperial line of our national polity lies in the fact that a historical world has been completed with the Imperial House at its center. The Imperial House of our country is not merely the center of a national state. The Imperial Way $(k \bar{o} d \bar{o})$ of our country contains the principle of world formation called 'Eight corners of the world under one roof'.

The principle of the formation of a global world does not deny the uniqueness of each state/nation but does exactly the opposite. People still think of the world as being abstract and general as seen in the eighteenth-century. What I mean by the formation of a global world is that the world will be united through concrete processes, that is, become a global world. When one talks about the world that becomes one it means that each state and nation have to fully live its respective historical life. This can be realized if each state/nation persistently accomplishes its world-historical mission on its own historical ground, that is, lives its own historical life. As seen in an organic body, for the whole to become one, each part must develop itself. For each part to develop itself, the whole must become one. ${ }^{6}$

(Translator's note) This passage was cited from the Imperial Rescript for the Conclusion of the Tripartite Pact between Japan, Germany, and Italy (1940).

6 (Translator's note) In other words, the self-realization of each part does not contradict the formation of the whole. 
By 'the world' I mean the [global] world that unifies individual uniqueness. The principle of the formation of a global world is nothing but allowing all states to obtain their own places. Today's statism (kokka shugi) must be based on such a principle of the formation of a global world. This does not simply mean that each state develops itself. Since the current world affairs inevitably drive the world to become one, each state must constantly follow its own statism. Thus, a particular world such as the Co-prosperity Sphere is needed to mediate between such plurality [nations] and singularity [a global world].

\section{$* * *$}

Basic guidelines for thought instruction and academic education for our nation must faithfully follow the true meaning of our national polity and base themselves on the understanding of historical realities and the principle of the formation of a global world. What we should denounce in Anglo-American thoughts is their imperialism that attempts to colonize East Asia with their sense of superiority. Domestic guidelines for thought instruction should not be totalitarianism because it often falls into partisanship. Instead, they must be based on the invariably fair Imperial Way in which the Emperor and his national subjects are united (kunmin ittai) while the whole nation assists the Emperor (banmin yokusan).

$* * *$

The above statement is the point of my talk on the matter of the new world order that was given at the request of the Research Institute of National Policy (Kokusaku Kenkyukai). That states/nations form a world by transcending themselves while persistently developing themselves does neither deny nor play them down. Instead, states/nations return to themselves and realize their own world-historical mission so that they are united to form a world. I call such comprehensive unification 'the world'.

The abstract world denying each state/nation is not real (jitsuzaiteki), nor can it be called 'the world'. Thus, I specifically use the term a 'global world'. The world has so far been [considered] abstract and non-existential. Today, however, the world is concrete and existential. No state/nation can exist simply on its own. Neither can it live without bearing close relationships to the world or without obtaining its own place in the whole world. The world is not merely external. The fact that the world is so existential today is the cause of the current world war. If we neglect this fact, we cannot solve the problem of the war.

Since what I mean by 'the world' is as mentioned above, the formation of a global world must follow regional traditions. Otherwise, the concrete world could not be constructed. What I mean by the principle of the formation of a global world is opposed to Anglo-American imperialism or federalism that colonizes others. It must be the globalism of 'Eight corners of the world under one roof' based on the spirit of the Imperial Way [kōdō seishin]. Abstract federalism is rather connected with imperialism behind the scenes. 
The concept of nation (minzoku) must be placed at the center for the formation of a historical world. Nation is a driving force for the formation of the world. Even in a co-prosperity sphere, nation as its central actor must be built historically and not selected abstractly, as seen in the League of Nations. This is how a true coprosperity sphere can be formed. However, mere nationalism is national egoism because it does not contain true globality, places its own nation at the center, and considers the whole world from such a self-centered position. What derives from it would inevitably fall into aggressionism or imperialism. Today, it is obvious that Anglo-American imperialism is based on national egoism.

It is not until a nation internalizes the principle of the formation of a global world that it can become a true state. Then the principle becomes a source of morality. Statism must not be confused with mere nationalism. What I mean by the principle of the formation of a global world does not contradict statism or nationalism. The formation of a global world is founded on nations. They constitute states as long as they attempt to form a global world. An individual takes up a moral mission as a member of a state. Thus, the principle of the formation of a global world means that each individual takes up his/her mission and responsibility in a unique historical place and time. The Japanese take up their own unique mission and responsibility as Japanese in this historical reality of Japan, that is, within the current state of affairs.

Just as nations become the source of morality for the formation a global world as mentioned above, so families become the source of morality on the same principle. Mere familism cannot be moralistic. The principle of the formation of a global world also contains familism. To the contrary, a co-prosperity sphere, as mentioned above, would not choose leader nations, but such nations must be born according to the principle of the formation of a global world. This is the fundamental difference between the principle of the formation of a global world and that of the League of Nations.

For the national polity (kokutai) of our country, Chronicles of the Authentic Lineages of the Divine Emperors (Jinnō Shōtōki) ${ }^{\dagger}$ stated "Great Japan is a divine country and unparalleled by any other foreign dynasties". The polity contains absolute historical globality. The unbroken lineage of our Imperial House connects the eternal past and the eternal future. This does not simply mean that the lineage is straight but inevitably means that it infinitely connects our beginning and end as the eternal [absolute] present. The principle that the beginning of heaven and earth begins today ${ }^{8}$ comes from this idea of unbroken lineage. Jihen" also stated "The age of gods exists in the present. Do not say that it was in the past" (Kuji Hongi Gengi). The quintessence of the Japanese spirit lies in the idea that the transcendent is the immanent while the immanent is the transcendent. 'Eight corners of the

(Translator's note) Jinnō Shōtōki 神皇正統記was authored by Kitabatake Chikafusa北畠親房 (1293-1354) who was a Japanese court noble and senior vassal of the Southern Court南朝in the $14^{\text {th }}$ century.

(Translator's note) This passage is cited from Jinnō Shōtōki.

9 (Translator's note) Jihen慈遍was a scholar monk in medieval Japan who authored Kuji Hongi Gengi 旧事 本紀玄義. 
world under one roof', or the principle of the formation of a global world, domestically works as the principle of 'The Emperor unified with his subjects' and 'The whole nation assisting the Emperor'. Even though our national polity (kokutai) is a familial state, one must not consider it merely familial [or internal]. The quintessence of our national polity should be that the internal is the external and the external is the internal. While the relationship between the Emperor and his subjects is seen as such in terms of righteousness [ginai kunshin], it can also be seen as the relationship between a father and his children in terms of affection [jōken fushi].

Since the quintessence of our national polity is, what I mentioned above, the principle of the formation of a global world does not mean that the subjectivity of our state is lost. This is exactly the principle of subjectivity unique to our country that empties oneself and embraces others. To be based on this principle means to infinitely extend the quintessence of our national polity to the world. It can be said that today's world-historical challenges are solved by the principle of our national polity. Not only should the UK and USA obey the principle, but also the Axis powers should follow this. 